Article

\title{
Gender Equality and De-Democratization Processes: The Case of Spain
}

\author{
Alba Alonso ${ }^{1, *}$ and Emanuela Lombardo ${ }^{2,3}$ \\ ${ }^{1}$ Department of Political Science and Sociology, University of Santiago de Compostela, 15782 Santiago de Compostela, \\ Spain; E-Mail: a.alonso@usc.es \\ 2 Department of Political Science and Administration, Madrid Complutense University, 28223 Madrid, Spain; \\ E-Mail: elombard@ucm.es \\ ${ }^{3}$ Instituto de Investigaciones Feministas, Madrid Complutense University, 28015 Madrid, Spain \\ * Corresponding author
}

Submitted: 11 February 2018 | Accepted: 14 June 2018 | Published: 14 September 2018

\begin{abstract}
Democracy is an ally of the feminist project and a necessary condition for its success. The European post-crisis context shows evidence of de-democratization processes that represent a remarkable challenge. This article investigates gender equality and processes of de-democratization in Spain in the aftermath of the 2008 economic crisis. It argues that neoliberalism, authoritarian shifts, and political corruption are three key dimensions of the processes of de-democratization in Spain that contribute to oppose gender equality. However, political contestation and feminist collective agency both in movements and institutions have played a key role in counteracting these dynamics. Civil society and feminist movements' struggles for democracy, equality and social justice, the role of new populist left parties in channeling some of the protesters' demands, gender equality institutions keeping gender on the agenda despite austerity cuts, and new local governments emerging from civic platforms after the 2015 elections have been effective in resisting attacks to Spanish democracy. A thorough revision of academic literature and other secondary sources helps to capture the specificities of this complex political setting.
\end{abstract}

\section{Keywords}

de-democratization; feminist project; gender equality; Spain

\section{Issue}

This article is part of the issue "The Feminist Project under Threat in Europe", edited by Mieke Verloo (Radboud University, The Netherlands) and David Paternotte (Université Libre de Bruxelles, Belgium).

(C) 2018 by the authors; licensee Cogitatio (Lisbon, Portugal). This article is licensed under a Creative Commons Attribution 4.0 International License (CC BY).

\section{Introduction}

Democracy is an ally of the feminist project and a necessary condition for its success (International Panel on Social Progress, 2016). In European countries with recent democratic transitions such as Spain, it has fostered the reintroduction of women's citizenship rights after the dictatorship, the creation of gender equality institutions, and the development of a specific policy and legal framework (Bustelo, 2016). Reflections on the concept of deep democracy establish quality criteria that, if put into practice, would intensify the positive impacts on gender equality (Tilly, 2007; International Panel on Social Progress, 2016; Walby, 2015). Yet, the European post-crisis context offers a rather different democratic scenario. Several member states have experienced unprecedented de-democratization processes that represent effective oppositions to gender equality, and a challenge for the feminist project (Aksoy, 2017; Kantola \& Lombardo, 2017a; Krizsan \& Roggeband, 2017; Kuhar \& Paternotte, 2017). Still, little is known about the specificities of this phenomenon across Europe and its gen-

\footnotetext{
${ }^{1}$ This article was written before the fall of Rajoy's PP conservative government in June 2018 due to a vote of no confidence promoted by the leader of PSOE socialist party Sánchez.
} 
eral implications. In this article we study the case of Spain $^{1}$ in the aftermath of the 2008 economic crisis starting from the following questions: what is the relation between de-democratization and gender equality dynamics? And how does the feminist project counteract these processes?

Democratization and de-democratization are two sides of a political process. We argue that neoliberalism, authoritarian shifts, and political corruption are three key dimensions of the processes of de-democratization in Spain that contribute to oppose gender equality. Spain was at the vanguard in European gender equality policies previous to the crisis (Valiente, 2006), thanks to the leading role of some regional governments and the impulse given by the Zapatero socialist cabinet. Recent changes have nuanced this situation. The subordination to the EU neoliberal project of Spanish economic and welfare policies, the limitation of civil rights to freedom of expression and women's autonomy, and the breaches to the rule of law and embezzling of public money by political authorities are the indicators we use to operationalize the three dimensions of de-democratization.

While neoliberalism, authoritarian shifts and political corruption allow us to capture the regression in Spanish democracy, the analysis also shows how political contestation and feminist collective agency both in movements and institutions have counteracted these dynamics, pushing towards democratization. Civil society and feminist movements' struggles for democracy, equality and social justice, the role of new populist left parties in channeling some of the protesters' demands, gender equality institutions keeping gender on the agenda despite austerity cuts, and new local governments emerging from civic platforms after the 2015 elections have been effective in resisting attacks to Spanish democracy. A thorough revision of academic literature and other secondary sources helps to capture the specificities of this complex political setting.

The following two sections introduce our analytical framework and the three dimensions of de-democratization and gender that we consider in this article-neoliberalism, authoritarian shifts and political corruption. The subsequent section, before conclusions, disentangles de-democratization processes in Spain and their relation with feminist struggles for democratization.

\section{De-Democratization and Gender: A Framework for Analysis}

Democracy and gender equality are interdependent. 'The more democracy, the more chances for gender equality; the more gender equality there is, the more chances for democracy' argues Verloo (2016, p. 36). Comparative data indicate a correlation between democracy and the status of women's health, education, economic participation and political empowerment (Tripp, 2013). Democratic polities allow more freedom to civil societies, and this increases the influence of women's organiza- tions on the state (Htun \& Weldon, 2010). In turn, feminist movements' ongoing struggles and challenges to processes of domination and exclusion contribute to democratize the political space (International Panel on Social Progress, 2016). Democracies are also more likely to promote gender equality than autocracies due to the creation of citizens that express more egalitarian attitudes (Inglehart \& Norris, 2003), and the existence of women's policy agencies and more state funds dedicated to gender equality policies (Tripp, 2013). It is therefore very relevant for the feminist project to detect shifts towards dedemocratization in currently consolidated democracies.

Democracy, in classical political science procedural definitions such as Dahl's (1971), has to do with the dimensions of 'contestation' (freedom to contest the conduct of a government) and 'participation' (who is included in the possibility to control the government). Minimum conditions for democratic systems are to present at least universal male and female suffrage, free, fair, competitive, and periodical elections, political pluralism, multi-party competition, freedom of expression, and different alternative sources of information (Morlino, 2009). While formal features of electoral democracy are very important, theorists of democratic deepening propose interpretations of democracy that both incorporate and go beyond electoral processes. The notion of 'relational democracy' developed by Ibarra (2008) conceptualizes democracy as a set of relations between citizens and decisionmakers that aims at facilitating a greater convergence between citizens' demands and political decision-making. These relations include dynamics of autonomous social mobilization and more stable channels of local participatory democracy, whose limitation would indicate de-democratization. Gender scholars are active in the theory of democratic deepening with the argument that the feminist project requires deep democracy (International Panel on Social Progress, 2016, p. 33; Walby, 2015, 2009). In deep democracy, contends Verloo (2016, pp. 34-36), not only procedural criteria are important and need to be expanded for structuring inclusive democratic debates, but also the 'practices and outcomes' of democratic rules are essential to allow civil society's ongoing contestation of political power and demand to address 'newly politicized problems'.

In that regard, Morlino (2009) states that a quality democracy involves procedural, responsiveness and substantive dimensions. Procedural dimensions of democracy include the rule of law and accountability. The rule of law requires, according to Morlino (2009), the application of law to everybody, no areas dominated by criminal organization, no corruption in public administration and political parties, competent, efficient and responsible bureaucracy, efficient police that is respectful of freedoms, easy and equal access to justice and independence of judiciary from the influence of political power. Accountability takes place through elections, control of the government by the opposition in parliament, by the courts, and by activities of political parties, media and other 
economic and social organizations. A quality democracy would also imply responsiveness to citizens' demands, full respect and expansion of freedom rights, and substantive equality in terms of civil, political, and social rights (Morlino, 2009).

Deep democracy requires state capacity to enforce its political decisions, according to Tilly (2007, p. 15), which means that a state is capable 'to supervise democratic decision-making and put its results into practice'. To study democratization and de-democratization as continuous processes, Tilly (2007, pp. 13-15) proposes four elements in the political relations between state and citizens that, read together, help to distinguish democratization from de-democratization: breadth, equality, protection, and mutually binding consultation. Breadth refers to wide political inclusion of people and their expressed demands; equality refers to extensive equality among categories of citizens in the translation of their demands in state action; protections is from the state's arbitrary action; and mutually binding consultation means that 'state agents have clear, enforceable obligations to deliver benefits by category of recipient' and there is no evidence that 'seekers of state benefits must bribe, cajole, threaten, or use third-party influence to get anything at all'. Thus, 'de-democratization', for Tilly (2007, p. 14), 'means net movement toward narrower, more unequal, less protected, and less binding consultation.'

Feminist approaches to democracy have contributed to develop visions of deep democracy from gender and other equality perspectives (Galligan, 2015; Kantola \& Lombardo, 2017b). Key dimensions of democracy in these approaches include not only gender balance in political decision-making but also substantive issues of social justice. A gender democracy for Galligan (2015) comprises dimensions of inclusion and recognition of women as well as accountability of the state with respect to gender equality commitments. The depth of democracy, according to Walby (2015, pp. 115-117, 2009), includes not only procedures to secure representation of groups such as women and minorities through quotas, but also 'the governance of major public services, such as finance, health, education and care services, through procedures that are democratically accountable, rather than through procedures focused on increasing profits for private owners' (Walby, 2015, p. 116). Democratic control therefore requires state regulation of markets.

Collective agency is another dimension of democratization that is relevant in feminist debates. The theory of social movements has conceptualized social mobilization, alliances among different movements, and framing processes to explain political change and democratization (Tarrow, 2011) also in times of economic crisis (Della Porta, 2017). Feminist scholars have shown the democratizing role of feminist struggles for both regimes in transition to democracy (Tripp, 2013; Waylen, 2007) and dedemocratizing regimes such as Erdoğan's Turkey (Aksoy, 2017) or Orbán's Hungary (Krizsan \& Roggeband, 2017). They also show the role of intersectional alliances for de- mocratizing the European public sphere (Siim \& Mokre, 2013). Alliances can also be forged between movement and institutional actors. Feminist collective agency operates in state structures that enact gender equality policies and can promote the feminist project particularly when they are connected to feminist movements (McBride \& Mazur, 2013).

Feminist struggles contribute to the project of deep democracy, argues Verloo (2016). The project of gender equality is intrinsically political in her view because it involves the ongoing struggle of feminists about the meaning of gender equality intersecting with other inequalities. Feminist struggles work for and at the same time need deepest forms of democracy because they challenge hegemonies and marginalizations within and outside the movement that can exclude groups and their demands from the debate. To accommodate these struggles, deep democracy requires not only formal rules but also effective equality practices and outcomes.

\section{Three Aspects of De-Democratization in Post-Crisis Europe}

The above debates tell us that democracy shows shifts towards de-democratization when procedural, responsiveness and substantive dimensions are not, or only partially, respected. In this article we limit our analysis to the following three dimensions of de-democratization that are relevant to understand gendered developments in the Spanish 2008 post-crisis context: neoliberalism; authoritarian shifts, and political corruption.

Neoliberalism implies processes of deregulation of the market and privatization of public services. This leads Walby to argue that 'the neoliberal project of deregulation is a project of de-democratization' (2015, pp. 117). Neoliberal logics of governance has led to the transference of state powers to non-elected state bodies, private enterprises, international organizations and financial institutions, with negative consequences for democratic control and management of public services in the interests of the population (Banaszak, Beckwith, \& Rucht, 2003, pp. 4-7; Hozic \& True, 2016). Walby states it clearly: 'the achievement of democratic depth requires the regulation of finance in the interests of the majority, not the minority' (2015, p. 117).

The European austerity agenda designed to enforce states' reductions in public spending includes measures that promote deregulation and liberalization of the labor market, through the reduction of labor rules, the decentralization of collective bargaining from state to enterprises, cuts in wages and in social policies (Busch, Hermann, Hinrichs, \& Schulten, 2013). Neoliberalism has therefore promoted a reduction in the role of the welfare state in favor of the market, with detrimental consequences for gender equality, women, and equality policies in Europe (Kantola \& Lombardo, 2017a; Karamessini \& Rubery, 2014; Walby, 2015). This reduction of the redistributive and equalizing capacity of the state in favor 
of the market has also consequences for deep democracy, leading to inequality and de-democratization (Tilly, 2007; Walby, 2015). Although neoliberalism creates problems for democracy in the absence of regulation, it is not always the opposite of democratization (for example, the argument of free market contributed to the adoption of the article on equal pay in the European Community Treaty of Rome, see van der Vleuten, 2007). However, in the context of the 2008 economic crisis neoliberalism has become more coercive and dangerous for democracy (Bruff \& Wöhl, 2016).

It is precisely in the context of Europe's economic crisis that authoritarian shifts have emerged, representing another critical dimension of de-democratization. As Bruff and Wöhl put it it is impossible to understand the post-2008 period without a central role being accorded to increasingly authoritarian state practices at a range of scales' (2016, pp. 93). Although neoliberalism and authoritarianism cannot be automatically connected, in Europe's post-crisis context austerity politics have led to processes of de-democratization in EU's and member states' political and economic decision-making (Kantola \& Lombardo, 2017a). EU's new economic governance regime has enforced strict rules of fiscal and monetary policies on member states that have bailed out failing banks. The new economic governance tools, that tie member states into a commitment to keep their annual budgetary deficit below $3 \%$ and their debt below $60 \%$ of GDP, challenge representative democracies by moving powers from parliamentary to executive branches of polities both at the national and supranational levels (Bruff \& Wöhl, 2016).

By moving decisions on economic politics away from Parliaments to less democratic institutions, this neoliberal logic of governance has had gender consequences. It has reduced the spaces of formal politics that women had formerly achieved (e.g., gender quotas are more often found for legislative than executive bodies) and has 'insulated' decision-making from feminist political contestation (Cavaghan, 2017). Similarly, these forms of 'disciplinary neoliberalism' (Gill \& Roberts, 2011, pp. 162) reshaped the state-market relationship by questioning the kind of services that are feasible and appropriate for public institutions to provide for or the subordination of the political agenda to the EU economic requirements that led Eurozone countries to adopt laws or even change their Constitution 'partially out of the reach of political debate and contestation' (Bruff \& Wöhl, 2016; Elomäki $\&$ Kantola, 2017, p. 235). These neoliberal shifts disproportionally affected women, challenging gender regimes across EU Member States (Walby, 2015).

The rise of authoritarianism is also visible in the threats to women's and LGTBQI rights across Europe. Farright political parties and movements have actively opposed same sex marriage and sexual and reproductive rights in several countries (Hodzic \& Bijelic, 2014; Kuhar \& Paternotte, 2017; Verloo, 2017). Transnational movements against what they call 'gender ideology' challenge liberal democracies by spreading conservative knowledge about gender roles and mobilizing to restrict civil rights and equality policies (Kuhar \& Paternotte, 2017). Limitations to the rights of participation and mobilization are indicators of authoritarian shifts (Ibarra, 2008). Social movements' contestation has been undermined by the political restriction of academic autonomy in Hungary and Turkey-with a specific challenge to gender and sexuality studies-, or the Spanish 'gag law' designed to criminalize social contestation (International Panel on Social Progress, 2016). These phenomena contribute to undermine the rise of feminist activism witnessed in recent years.

Political corruption represents a third critical dimension of de-democratization. Good quality democracy requires a normal functioning of the rule of law, which relies not only on the effective application of the legal framework but also on the pre-eminence of the common good as a guiding principle of government (Morlino, 2009). Corruption subverts both premises by yielding 'the supremacy of particular interests in public decisions and, thus, the exercise of authority for the sake of a few' (Villoria, Jiménez, \& Revuelta, 2014, p. 198). In so doing, it has deep implications for other democratic dimensions such as responsiveness to citizens' demands or substantive equality.

Feminist scholars have analyzed the genderedness of corruption. Initial studies hypothesized that women's risk aversion and their more ethical behavior lay behind the correlation between increased female presence in the political arena and lower levels of perceived corruption (Dollar, Fisman, \& Gatti, 2015). Both experimental and non-experimental studies have nevertheless problematized this relationship. The inconsistency of the results obtained as well as the explanatory capacity of other variables related to the quality of democracy, stressed the need for a less 'essentialist' perspective (Goetz, 2007; Sung, 2012). Feminist institutionalism provided here the analytical tools to adopt a nonindividualistic approach to the study of corruption (Johnson, Einasdottir, \& Petursdottir, 2013). Informal rules and 'logics of appropriateness' shape women's capacity to engage in non-honest behaviors (Frank, Lambsdorff, \& Boehm, 2011). As political outsiders, they lack access to the all-male networks through which corruption functions. More importantly, this phenomenon becomes the process 'through which typically male-dominated elites transgress proclaimed values of accountability, transparency, and equality' (Johnson et al., 2013, p. 196).

The gendered effects of corruption are multidimensional. Women suffer a greater impact of these practices, as they have a more direct contact with the public sector and are more vulnerable to inefficient public services (Stensota, Svensson, \& Wängnerud, 2015). Due to this, they report higher levels of victimization (Villoria et al., 2014). Political corruption also undermines the effectiveness of gender equality policies. While budget cuts that are connected to the squandering of pub- 
lic funds are likely to hit this policy area first, due to a general lack of prioritization of gender equality (Lombardo, 2017a), corruption also jeopardizes policy strategies such as gender mainstreaming and electoral quotas. Clientelism has proved to be detrimental to women's political recruitment, as the pre-eminence of informal networks tends to reproduce male dominance in political parties (Bjarnegård, 2013). Similarly, the implementation of gender equality measures included in public procurement regulations remains ineffective if corrupted practices are in place.

\section{Disentangling De-Democratization and Democratization Processes in Spain}

This section disentangles the three de-democratization dimensions we address in this article-neoliberalism, authoritarian shifts and political corruption-in the case of Spain, with reference to their gender and democratization dynamics.

\subsection{Neoliberalism}

The neoliberal EU and Spain's political response to the economic crisis in terms of austerity negatively affected democracy, social rights, and gender equality in Spain. Neoliberal de-democratization hit the Spanish Constitution in 2011, when the failing banks crisis was transformed into a public debt crisis. Following strong EU pressure from the European Central Bank, through a letter to former Prime Minister Zapatero including an agenda of imperative reforms, the socialist government changed the Constitution by committing Spain to limit its budget deficit within the EU and member states established targets, in the middle of August, through an emergency procedure with little parliamentary debate (Bruff \& Wöhl, 2016; El País, 2014).

Since 2011, the EU and Spain's austerity politics in response to the crisis through National Reform and Stability Programs has promoted a neoliberal agenda of cuts to public budgets and welfare policies, deregulation of the labor market, tax increases, liberalizations and privatizations of public services (Lombardo, 2017a). In relation to gender equality policies, this neoliberal turn led not only to the restructuring and dismantlement of gender equality institutions, but also to a significant decrease in the government's budget dedicated to gender equality policies at all governmental levels, reaching less 34.1\% at the central level in the 2009-2013 crisis period (Paleo \& Alonso, 2014). Governmental funding dedicated to policies against gender violence has been decreasing from 2008 onwards, with the budget laws continuing this trend with $22.5 \%$ in 2016 and freezing funds in 2017 (Gobierno de España, 2016). The Spanish welfare state suffered from budget cuts in education, care, social assistance, family policies, and health (Pavolini, León, Guillén, $\&$ Ascoli, 2015). The universality of the health system was attacked through the cancellation of primary care for undocumented migrant people (except for emergencies, children, and pregnancies), that the conservative government enforced through the Royal Decree 16/2012 (Lombardo, 2017b).

As Tilly (2007) and Walby (2015) argue, the restriction of social rights and the diminishing governance of major public services, by reducing the intervention of the state in the correction of inequalities produced by the market, through redistribution via democratically accountable procedures, has negative consequences for the quality of democracy. Yearly reports on the quality of democracy in Spain's post-crisis context show that the experts' evaluation barely reaches the mark of 5.2 in a 0-10 scale due to the restriction of social rights and the inequalities that the system produces (Fundación Alternativas, 2015). Data from European and national surveys show that Spanish citizen's dissatisfaction with democracy has increased abruptly during the crisis, not only due to economic hardships but also due to the political management of the crisis' and the 'intervention in democratic processes of national and international institutions and markets, whose legitimacy is questioned' (Fundación Alternativas, 2015, p. 26).

Democratization and gender dynamics show women's resilience and feminist and civil society struggles against neoliberal austerity politics. Despite the worsening labor market conditions that forced them into more exploitative situations, the Spanish gender regime is not becoming more 'domestic' yet. Spanish women's activity rate is still high-53.4\% in 2017 (INE, 2017) - thus showing that women are not 'going back home' (Lombardo, 2017a). Anti-austerity struggles in Spain connected the defense of social rights and democracy from the beginning of the protest of the Indignados movement on 15 May 2011. The movement, that continued through 'waves' of civic activism, demanded 'real democracy', criticized austerity measures, and supported welfare policies such as public health, education, housing, and gender equality (Calvo, 2013; Cruells \& Ruiz, 2014). Feminists have gendered the Indignados movement and have led important platforms such as the Platform of people affected by house evictions (PAH) headed by Ada Colau, who would be elected mayor of Barcelona in the 2015 municipal elections.

Feminists also developed their own anti-austerity struggles, through the organization of feminist strikes to defend a broader concept of both productive and reproductive work, such as the General Women's Strike that in 2018 mobilized 6 million women (see La Vanguardia, 2018). Finally, austerity pushed feminist organizations in Spain to intensify their state-level mobilization strategies, opening the space to greater democratization. By 2008 six editions of UN Shadow reports had been issued by feminist organisations worldwide, a practice that had begun in 1993. It was not until then that a group of 17 Spanish feminist organizations drafted their own Shadow report for the first time. Their second UN Shadow report from 2013 created a wider platform of 
more than 50 feminist organizations that through a twoyear participatory process produced a Shadow Report that was signed by 277 Spanish feminist organizations (San José, 2015). The UN used this Shadow Report to criticize the Spanish government for the deterioration of gender equality in the last years and to urge the government to comply with its international commitments (Lombardo, 2017a; Plataforma CEDAW Sombra-España, 2015). Institutional collective agency at the regional level has played an important role too in keeping gender equality on the agenda, as shows the maintenance of budgets dedicated to gender equality in times of austerity by women's policy agencies of the Basque Country and Andalusia (Alfama, 2017). Feminist agency in movements and in some regional institutions has thus been crucial for democratization.

\subsection{Authoritarian Shifts}

The construction of an 'emergency' situation to face the economic crisis in Europe has moved the Spanish government to take decisions that are considered authoritarian shifts, such as the aforementioned fast constitutional reform to limit budget deficit (Bruff \& Wöhl, 2016). The quality of Spanish democracy has decreased even further under conservative ruling. As Villoria et al. (2014) argue, the key factor explaining differences in the quality of government among European regions is the historical development of effective institutional constraints (parliaments, courts, media) to the power of the executive. These constraints have weakened in Spain from 2011 onwards. During the first term of the conservative Prime Minister Rajoy, his cabinet broke the record of the number of initiatives approved by Decree-law (García De Blas, 2015). This type of norm, that the Constitution foresees for cases of 'extraordinary and urgent need', implies shorter periods of debate in parliament and the impossibility for the opposition to present amendments. The crisis context was used as an alibi to circumvent the legislative branch and reform key policies such as taxation, employment, and access to healthcare.

Similarly, the conservative government used its majority to undermine the capacity of parliament to effectively control the government. From 2011 to 2015 the Partido Popular [Popular Party] (PP) rejected up to 70 petitions of the opposition to enquire the prime minister in parliament. Rajoy also refused to properly address the press during that period, declining to be present in press conferences and to answer questions. He remained thus rather unaccountable not only for the unpopular austerity decisions taken during the economic crisis but also for the numerous corruption cases that affected his party. Weakened constraints to the executive branch and less accountability were not only detrimental to democracy but also to gender equality. This is due respectively to the fact that legal gender quotas in Spain promote women's access to the legislative but not the executive branch, and that the Prime Minister's lowered accountability reduced opportunities for the opposition and the press to question the government's budget cuts to welfare and gender equality policies.

Lack of accountability was only one aspect of dedemocratization. The restriction of freedom of expression, participation, and other human rights through the 2014 'Law of protection of citizens' security', or 'gag law' as civil society renamed it, has exposed the government's undemocratic reaction against the social contestation that occurred in Spain from the Indignados movement onwards. The 'gag law' limits the freedom of expression, association, protest, and information, by establishing administrative sanctions with high fines for incompliant actors, by increasing police powers and their testimony in trial as compared to affected citizens, or by limiting the freedom of information and collection of proof about possible police abuse (Gobierno de España, 2015). This doubtfully democratic law, that has caused citizen and media sanctions ${ }^{2}$ and self-censorship, has also had direct gender impacts due to its effects on the mobilization of feminist movements and the platform of people affected by house evictions. Moreover, it has triggered protests by sex workers' associations since the increased powers given to the police have promoted a boost in their abusive behavior and sanctions to sex workers on the basis of the law's articles that punish disobedience or resistance to authority-for instance, when they resist to show their identity documents (Borraz, 2016). Authoritarian shifts also showed in the Catalan secessionist tensions of 1st October 2017. The police' disproportionately violent attacks against Catalan citizens voting in a referendum for independence (which the Constitutional Court declared unconstitutional) injured hundreds of people and was criticized by the Human Rights organizations (see Jones \& Burgen, 2017; Human Rights Watch, 2017).

Conservative attacks to women's sexual and reproductive rights in Spain have mostly been perpetrated by the main conservative party in alliance with 'pro-life' grass-roots organizations. The PP government, elected in 2011, presented a bill to restrict the right to abortion by reforming the progressive 2/2010 law on sexual and reproductive health approved under former socialist ruling. The 'Bill of protection of the life of the embryo and of the rights of the pregnant woman' would make abortion illegal and provoke a deterioration of women's autonomy and health. Strong and continued mobilization of the Spanish feminist movement, alliances with international actors, and internal divisions in the conservative party led the prime minister to withdraw the bill and forced the resignation of the minister of justice that proposed it (El País, 2014; Lombardo, 2017a; Alonso \& Paleo, 2017). The struggle to defend the right of abortion was a success story for the feminist movement and for democracy, since it showed the importance of political contes-

\footnotetext{
2 Under the new 'gag law', from July 2015 to December 2016, the Spanish police issued more than 22000 and 16000 fines respectively for disrespect and disobedience to police officers (see Borraz, 2016).
} 
tation for defending women's civil rights (Alonso, 2015; García, 2015). Still, young women's rights were restricted through the 2015 reform of the current abortion law so that women under 18 will need to obtain their parents' consent to have an abortion.

Moreover, pro-life organizations were very successful in seizing the multilevel opportunity structures offered by the Spanish quasi-federal state (Alonso \& Paleo, 2017). At the time the socialist cabinet drafted Law 2/2010, these grass-roots groups presented 'Citizens Legislative Initiatives' ${ }^{3}$ in all the Autonomous Communities, claiming the need for policies to support pregnant women and to provide alternatives to abortion. Regions governed by PP approved pro-life laws and policy plans that stated a public duty to protect the life of the un-born and to set up a network of assistance to pregnant women in vulnerable positions. In these regions, the few economic resources that were dedicated to gender equality policies are now destined to policies that depict women as mothers and to these very same organizations that oppose feminist and LGBTI movements (Alonso \& Paleo, 2017). ${ }^{4}$ More importantly, nowadays these groups enjoy direct access to women seeking advice on their sexual and reproductive rights, undermining in practice statelevel policies that grant women an informed decision in a safe environment. The conservative political discourse on sexual and reproductive rights in Spain's regions produces knowledge about traditional gender roles and restriction to women's autonomy, which implies a retrocession for gender equality (Verloo, 2017).

Dynamics of democratization point at the role of political contestation as vital for democracy (International Panel on Social Progress, 2016; Walby, 2015). The Indignados movement and the following waves of social and feminist protest brought back political contestation in Spain. The emergence of new political parties such as Podemos and Ciudadanos introduced more pluralism in the Spanish two-party system of PP and Partido Socialista Obrero Español [Socialist Party] (PSOE). The new parties not only allow broader institutional channeling of citizens' demands but also demand greater accountability to a government used to govern in absolute majority. The alliance of Podemos with civic platforms at the 2015 local elections (e.g., Ahora Madrid, Barcelona en Comú) has allowed people from civil society and not only party apparatus to enter representative institutions. By opening institutional channels to represent some of the Indignados movement demands (Calvo \& Álvarez, 2015), the new political actors could affect the agenda of civil rights restrictions of the last decade. One example is the opposition parties' proposal of reform of the 'gag law' started in March 2017.

These political changes have had important gender effects. The representation of women in the 2015 gen- eral elections was the highest in Spain's democratic history, reaching $39.4 \%$ in Congress, due to the adoption of voluntary zipper-system candidate lists in the PSOE, Podemos, and Izquierda Unida [United Left] (IU) parties (Lombardo \& Verge, 2017). The victory of civic lists in alliance with Podemos party in the 2015 local and regional elections led to the renovation of local governments through civic lists in towns such as Madrid, Barcelona, Valencia or Santiago. It also provoked the election of female progressive mayors coming from civil society in Madrid and Barcelona and the opening of a window of opportunity for gender equality policies. In the municipal government of Barcelona, for example, a new equality institution was created, the Department of Feminisms and LGBTI, led by gender mainstreaming and intersectionality experts. Policies have aimed at counteracting intersectional inequalities that tend to increase in times of crisis through measures such as the Plan for Gender Justice (2016-2020) or the Strategy Against the Feminization of Poverty and Precariousness (2016-2024) (Lombardo, 2017b). Similarly, new leftist governments in regions like the Balearic Islands and Valencia prioritized reinstating women's sexual and reproductive rights and repealed the laws and plans supported by pro-life organizations (Alonso \& Paleo, 2017).

\subsection{Political Corruption}

The post-2008 period is characterized by the rise of corruption as a key political problem for Spanish democracy. In 2015, the country reached its record and was placed 41 in the International Transparency's Corruption Perceptions Index (0 highly corrupt, 100 very clean). By that point, scandals involving the main state institutions-from the monarchy to the regional governments and the main parties-were central to the political debates. National surveys reflected indeed that citizens placed 'corruption and fraud' (42\%) and 'politicians, political parties, and politics' (29.9\%) as the main problems of the country just below 'unemployment' (69.6\%) (CIS, 2016). Corruption has provoked the most significant decline of institutional trust amongst European countries (Torcal, 2014), which affects the three government branches. Structural problems of Spanish democracy such as the 'politicization' of the judiciary, the lack of control over party finances or the need for more transparency policies became more acute (Group of States against Corruption [GRECO], 2016), gathering attention also from the EU institutions, which included anticorruption measures as part of the country's Stability Programme (European Commission, 2017).

This state of affairs has had significant gendered implications. First, the increased perceived level of corruption has shown remarkable potential to erode the pub-

\footnotetext{
${ }^{3}$ The Spanish Constitution foresees the possibility for citizens to gather a particular number of individual endorsements for the submission of a bill that would be then debated and considered for approval in Parliament. Pro-life organizations pioneered the use of this participatory device in many Spanish regions.

${ }^{4}$ In the region of Galicia, for instance, pro-life and religious organizations, in 2016, obtained $77 \%$ of the funds devoted to the services to support pregnant women (Alonso \& Paleo, 2017).
} 
lic support for the welfare state. Studies have revealed that although Spaniards endorse key social policies such as education and health, they show increasing skepticism about greater levels of taxation and about public spending in non-priority areas-where gender equality policies are likely to be included (Calzada \& Del Pino, 2016). Existing data confirm citizens' fears over inefficient public spending. Recent figures by the National Commission for Market and Competition (CNMC) estimate the impact of corruption practices related to public procurement on an extra cost of 47,500 million Euros-around a $4.5 \%$ of the GDP (Navas, 2015).

As the literature predicted, women are less likely to have access to the clientelist networks involving top businessmen and politicians. Data gathered by the judiciary confirm that amongst the 1,378 people that were brought to court between July 2015 and September 2016 in relation to corruption, $77 \%$ were men (General Council of the Judiciary, 2017). Women not only suffer the effects of the under-funding of the welfare state, but also lack access to these male dominated networks, based on homosocial capital (Bjarnegård, 2013), through which public money is (re)located without any democratic scrutiny. Moreover, these practices of awarding public contracts in exchange for black money-to illegally fund the party and/or its members-have serious implications for gender mainstreaming practice. The Spanish equality framework, including the national 'Law 3/2007 on Effective Equality between Men and Women', establishes the duty of public institutions to enact equality clauses in public procurement related contracts and regulations. Corruption has, however, undermined this attempt to incorporate gender equality measures in the private sector.

As a key preoccupation of the Spanish population, corruption has also been at the heart of social struggles for democratization. Fueling the Indignados movement, whose indignation was targeted at corrupted politicians that were not perceived as good representatives, it has inspired political discourses against the establishment. Indeed, new politics in Spain, both at the right and at the left, cannot be understood without the allegations against the old parties-PSOE and PP-and their close connection to political scandals. Here, Podemos holds the more critical discourse and places Spain close to a 'mafia state', where the institutions have been subordinated to the interests of the PP and the economic elite, serving as an effective tool for the illicit funding of the party and its members, and the control over the allocation of public spending for the benefit of clientelist networks. The party has proposed, on 19 May 2017, a vote of no confidence on the PP government on grounds of these corrupted practices that disrespect democracy and increase inequality (Riveiro, 2017). Up to 800 public officers of PP are currently being sued for corruption, including charges based on their participation in organized crime-in cases such as Gürtel or Púnica (Mira, 2017).

Feminist struggles have not remained aloof to this key dimension of de-democratization. The women's movement enjoyed a leading role in anti-austerity platforms that have defended the public sector from privatizations that tend to place public services under the control of the same companies involved in corrupted practices (Lombardo, 2017a). Women also actively participated in civic platforms that contributed to prosecute these activities such as $15 \mathrm{M} \mathrm{Pa} \mathrm{Rato-against} \mathrm{corruption}$ in the finance sector-or the Platform Against the Privatization of the Isabel II Canal-to protect the public water supply in Madrid from the embezzlement of public money. With similar aims, some regional and local governments have adopted public procurement regulations that allowed re-instating gender equality clauses, which are particularly advanced in terms of gender mainstreaming, especially in Basque and Catalan equality institutions (Diz, 2017).

\section{Conclusions}

De-democratization processes oppose the feminist project in Europe. Feminist analyses contribute to disentangle these setbacks, which have significant implications not only for the procedural and substantive components of a deep democracy, but also for the situation of women in Europe. This article has analyzed the relation between gender equality and processes of dedemocratization in Spain in the aftermath of the 2008 economic crisis. It argued that neoliberalism, authoritarian shifts and political corruption have been detrimental to Spanish democracy and gender equality. The subordination of the common good to the EU neoliberal project, the limitation of civil rights to freedom of expression, mobilization, and women's autonomy, breaches to the rule of law or the embezzling of public money by political authorities undermine procedural and substantive democracy. Such phenomena not only affect the state capacity of effective democratic control of decision-making and of putting its results into practice in Tilly's (2007) terms, but have significant gendered impacts. These include the dismantling of key public services, including gender equality policies, the restriction of women's sexual and reproductive rights, and the ineffective implementation of gender mainstreaming. Combined they have undermined progress made in the Spanish equality policy and legal framework in the previous decade.

However, collective agency has played a key role in counteracting these dynamics and re-democratizing the political space in Spain. Civil society and feminist movements' struggles for democracy, equality and social justice, have been effective in protecting public services from privatization, bringing corrupted politicians to justice or assuring women's access to safe abortions. They also triggered the most significant change in the Spanish party system in decades, opening opportunities for the rise of left-wing party Podemos, and especially of local governments emerging from grass-roots platforms, which are currently the avant-garde in the implementation of gender equality policies in Spain. Moreover, gen- 
der equality institutions in some regions have still prioritized gender equality despite austerity. The Spanish multilevel structure provided opportunities to circumvent the PP majority at the state level (Alonso \& Verge, 2014) and partially reverse the setbacks in gender equality policies of the last decade.

Collective agency has thus offered political opportunities for counteracting opposition to feminism and putting forward visions of a deep-and feministdemocracy. Yet, the potential for a deep democracy is based on the interdependent relation between democracy and gender equality. To be able to express their democratizing action, feminist and social movements need rules and practices that do not restrict their rights and possibilities of political contestation. It is to be seen whether the dynamics of de- and re-democratization will safeguard Spanish democracy and gender equality in these internationally hard times.

\section{Acknowledgements}

We wish to thank the editors of this thematic issue, Mieke Verloo and David Paternotte, the anonymous reviewers, as well as Birte Siim and Sylvia Walby, for their constructive comments. We are also thankful to Eduardo Jáuregui for proofreading the text.

\section{Conflict of Interests}

The authors declare no conflict of interests.

\section{References}

Aksoy, H. A. (2017). Understanding democratic reversal from a gender perspective: The curious case of Turkey. Paper presented at the ECPG Conference, Lausanne, Switzerland.

Alfama, E. (2017). ¿Transformando el estado? Avances y obstáculos en la implementación del mainstreaming de género [Transforming the state? Developments and obstacles in implementing gender mainstreaming] (Unpublished Doctoral Dissertation). Universidad Autónoma de Barcelona, Barcelona, Spain.

Alonso, A. (2015). Las políticas de género en España: Retrocesos y resistencias en tiempos de austeridad [Gender equality policies in Spain: Setbacks and resistances in times of austerity]. ExAequo-Revista da Associação Portuguesa de Estudos das Mulheres, 32, 33-48.

Alonso, A., \& Verge, T. (2014). Territorial dynamics and gender equality policies in Spain. Revue FédéralismeRégionalisme, 14. Retrieved from http://popups.ulg. ac.be/1374-3864/index.php?id=1365

Alonso, A., \& Paleo, N. (2017). Políticas de salud sexual y reproductiva en España: Contra-movimientos y marcos interpretativos en conflicto [Sexual health and reproductive policies in Spain: Counter-movements and conflicting policy frames]. Revista Española de
Sociología, 26(3), 59-76.

Banaszak, L. A., Beckwith, K., \& Rucht, D. (2003). When power relocates: Interactive changes in women's movements and states. In L. A. Banaszak, K. Beckwith, \& D. Rucht (Eds.), Women's movements facing the reconfigured state (pp. 1-29). Cambridge: Cambridge University Press.

Bjarnegård, E. (2013). Gender, informal institutions and political recruitment. explaining male dominance in parliamentary representation. Basingstoke: Palgrave Macmillan.

Borraz, M. (2016, November 29). La Ley Mordaza, contra las prostitutas: "Somos multadas y criminalizadas" [The gag law, against prostitutes: "We are fined and criminalized"]. El Diario. Retrieved from https:// www.eldiario.es/sociedad/Ley-Mordaza-prostitutasmultadas-criminalizadas_0_585492205.html

Borraz, M. (2017, May 27). La Policía multa con la Ley Mordaza a más de 1.200 personas al mes por "faltas de respeto" a los agentes [Thanks to the Gag Law the police fines more than 1200 people a month for being 'disrespectful' with police officers]. El Diario. Retrieved from http://www.eldiario.es/sociedad/ Policia-Ley-Mordaza-personas-respeto_0_64743564 5.html

Bruff, I., \& Wöhl, S. (2016). Constitutionalizing austerity, disciplining the household. In A. Hozic \& J. True (Eds.), Scandalous economics: Gender and the politics of financial crises (pp. 92-108). Oxford: Oxford University Press.

Busch, K., Hermann, Ch., Hinrichs, K., \& Schulten, T. (2013). Euro crisis, austerity policy and the European social model. How crisis policies in southern Europe threaten the EU's social dimension. Friedrich Ebert Stiftung. Retrieved from http://library.fes.de/pdffiles/id/ipa/09656.pdf

Bustelo, M. (2016). Three decades of state feminism and gender equality policies in multi-governed Spain. Sex Roles, 74(3/4), 107-120.

Calvo, K. (2013). Fighting for a voice: The Spanish 15$\mathrm{M} /$ Indignados movement in Spain. In L. Cox \& C. Flesher Fominaya (Eds.), Understanding European movements: New social movements, global justice struggles, anti-austerity protest (pp. 236-253). London: Routledge.

Calvo, K., \& Álvarez, I. (2015). Limitaciones y exclusiones en la institucionalización de la indignación: Del 15-M a Podemos [Limits and exclusions in the institutionalization of indignation: from15M to Podemos]. Revista Española de Sociología, 24, 123-131.

Calzada, I., \& del Pino, E. (2016). Actitudes ante la redistribución: ¿Cómo ha afectado la crisis? [Attitudes towards redistribution: What has been the effect of the crisis?]? Revista del Tercer Sector, 33, 65-90.

Cavaghan, R. (2017). The gender politics of EU economy policy: Policy shifts and contestations before and after the crisis. In J. Kantola \& E. Lombardo (Eds.), Gender and the economic crisis in Europe. Politics, institu- 
tions and intersectionality (pp. 49-72). Basingstoke: Palgrave.

CIS. (2016), Barometer April 2016 (Study no 3134). Madrid, Spain: Centro de Investigaciones Sociológicas.

Cruells, M., \& Ruiz, S. (2014). Political intersectionality within the Spanish Indignados social movement. Research in Social Movements, Conflicts and Change, 37, 3-25.

Dahl, R. (1971). Polyarchy: Participation and opposition. New Haven, CT: Yale University Press.

Della Porta, D. (2017). Can democracy be saved? Cambridge: Polity.

Diz, I. (2017). Las clausulas sociales en la contratación pública: ¿Una herramienta del mainstreaming de género? Paper presented at the AECPA conference, Santiago de Compostela, Spain.

Dollar, D., Fisman, R., \& Gatti, R. (2015). Are women the fairer sex? Corruption and women in government. Journal of Economic Behaviour and Organization, 46, 423-429.

El País. (2014, September 9). The abortion law, story of a failure. El País.

El País. (2014, November 24). El artículo 135 de la Constitución, antes y después de la reforma de 2011 [The article 135 of the Constitution, before and after the 2011 reform]. El País. Retrieved from https:// elpais.com/politica/2014/11/24/actualidad/1416849 910_452980.html

Elomäki, A., \& Kantola, J. (2017). Austerity politics and feminist resistance in Finland: From established women's organizations to new feminist initiatives. In J. Kantola \& E. Lombardo (Eds.), Gender and the economic crisis in Europe. politics, institutions and intersectionality (pp. 231-256). Basingstoke: Palgrave.

European Commission. (2017). Recommendation for a council recommendation on the 2017 national reform programme of Spain and delivering a council opinion on the 2017 stability programme of Spain. Brussels, Belgium: European Commission.

Frank, B., Lambsdorff, J. G., \& Boehm, F. (2011). Gender and corruption: Lessons from laboratory corruption experiments. European Journal of Development Research, 23(1), 59-71.

Fundación Alternativas. (2015). Informe sobre la democracia en España 2015 [Report on democracy in Spain 2015]. Fundación Alternativas. Retrieved from www.falternativas.org

Galligan, Y. (2015). States of democracy: An overview. In Y. Galligan (Ed.), States of democracy: Gender and politics in the European Union (pp. 1-14). New York, NY: Routledge.

García, J. (2015). Feminismos en tiempos de resistencias a la austeridad y confluencias por la ruptura con el 78 [Feminisms in times of resistances to austerity and coalitions to break with the 78 regime]. In Anuario Movimientos Sociales 2014. Bizkaia: Fundación Betiko.
García De Blas, E. (2015, August 21). El Gobierno de Rajoy bate el récord de legislar por decreto [Rajoy's cabinet breaks the record for legislating via decree]. El País. Retrieved from https://elpais.com/politica/ 2015/08/19/actualidad/1440011805_580128.html

General Council of the Judiciary. (2017). El CGPJ reúne los principales indicadores de la actividad judicial contra la corrupción en un repositorio de acceso público [The CGPJ gathers the main indicators of judicial activity against corruption in a public database]. General Council of the Judiciary. Retrieved from http://www. poderjudicial.es/cgpj/es/Poder-Judicial/En-Portada/ El-CGPJ-reune-los-principales-indicadores-de-la-acti vidad-judicial-contra-la-corrupcion-en-un-repositorio -de-acceso-publico-

Gill, S., \& Roberts, A. (2011). Macroeconomic governance, gendered inequality, and global crises. In B. Young, I. Bakker, \& D. Elson (Eds.), Questioning financial governance from a feminist perspective (pp. 155-172). London: Routledge.

Gobierno de España (2015). Ley Orgánica 4/2015, de 30 de marzo, de protección de la seguridad ciudadana [Organic Law 4/2015, 30th of Marcha, on the protection of citizens' safety]. Retrieved from https://www. boe.es/diario_boe/txt.php?id=BOE-A-2015-3442

Gobierno de España. (2016). Proyecto presupuestos generales del Estado 2017 [Bill on the general state's budget 2017]. Madrid: Gobierno de España. Retrieved from http://www.sepg.pap.minhafp.gob.es/ Presup/PGE2017Proyecto/MaestroTomos/PGE-ROM/ MnSerieRoja.htm

Goetz, A. M. (2007). Political cleaners: Women as the new anti-corruption force? Development and Change, 38(1), 87-105.

Group of States against Corruption. (2016). Forth evaluation round. compliance report Spain. Strasbourg, France: Council of Europe.

Hodzic, A., \& Bijelic, N. (2014). Neo-conservative threats to sexual and reproductive health and rights in the European Union. Zagreb: CESI.

Hozic, A., \& True, J. (Eds.). (2016). Scandalous economics: Gender and the politics of financial crises. Oxford: Oxford University Press.

Htun, M., \& Weldon, L. (2010). When do governments promote women's rights? A framework for the comparative analysis of sex equality policy. Perspectives on Politics, 8(1), 207-216.

Human Rights Watch. (2017). Spain. Police used excessive force in Catalonia. Human Rights Watch. Retrieved from https://www.hrw.org/news/2017/ 10/12/spain-police-used-excessive-force-catalonia

Ibarra, P. (2008). Relational democracy. Reno: Center for Basque Studies.

INE. (2017, first trimester). Encuesta de población activa. Inglehart, R., \& Norris, P. (2003). Rising tide: Gender equality and cultural change around the world. Cambridge: Cambridge University Press.

International Panel on Social Progress. (2016). The 
challenge of gender inequality. In Rethinking society for the 21st century (Chapter 14). Retrieved from https://comment.ipsp.org/chapter/chapter-14inequality-challenge-democracy

Johnson, J. E., Einasdottir, P., \& Petursdottir, G. M. (2013). A feminist theory of corruption: Lessons from Iceland. Politics \& Gender, 9, 174-206.

Jones, S., \& Burgen, S. (2017, October 2). Catalan leader calls for mediation with Spain over independence. The Guardian. Retrieved from https://www. theguardian.com/world/2017/oct/02/catalan-govern ment-emergency-meeting-spain-independence

Kantola, J., \& Lombardo, E. (2017a). Gender and the economic crisis in Europe. Politics, institutions, and intersectionality. Basingstoke: Palgrave.

Kantola, J., \& Lombardo, E. (Eds.). (2017b). Gender and political analysis. Basingstoke: Palgrave.

Karamessini, M., \& Rubery, J. (Eds.). (2014). Women and austerity: The economic crisis and the future for gender equality. London: Routledge.

Krizsan, A., \& Roggeband, C. (2017). State reconfigurations and domestic violence policy regimes. Paper presented at the ECPG Conference, Lausanne, Switzerland.

Kuhar, R., \& Paternotte, D. (Eds.). (2017). Anti-gender campaigns in Europe: Mobilizing against equality. London: Rowman \& Littlefield.

La Vanguardia. (2018, March 3). Seis millones de trabajadores secundan la huelga feminista, según los sindicatos [Six million workers participate on the feminist strike, according to the trade unions]. La Vanguardia. Retrieved from http://www.lavanguardia. com/economia/20180308/441354667931/dia-mujer -8m-huelga-feminista-manifestaciones.html

Lombardo, E. (2017a). The Spanish gender regime in the EU context: Changes and struggles in the wake of austerity policies. Special issue on gender equality and austerity. Gender, Work \& Organization, 24(1), 20-33.

Lombardo, E. (2017b). Gender equality policies in Spain-Update (Policy Department C: Citizens' Rights and Constitutional Affairs, PE.583.112). Strasbourg and Brussels: European Parliament.

Lombardo, E., \& Verge, T. (2017). Cuotas de género en política y economía: Regulación y configuración institucional en España [Gender quotas in politics and corporate boards: Regulation and institutional configuration in Spain]. Política y Gobierno, 24(2), 301-331.

McBride, D., \& Mazur, A. (2013). Women's policy agencies and state feminism. In G. Waylen, K. Celis, J. Kantola, \& L. Weldon (Eds.), The Oxford handbook of gender and politics (pp. 654-678). Oxford: Oxford University Press.

Mira, N. (2017, May 25). Lezo, Gürtel y Púnica: Los tentáculos de la hidra de corrupción del PP. [Lezo, Gürtel y Púnica: The tentacles of the corruption hydra of the PP]. $A B C$. Retrieved from https://www. abc.es/espana/abci-lezo-gurtel-y-punica-tentaculos- hidra-corrupcion-pp-201705242157_noticia.html Morlino, L. (2009). Democracias y democratizaciones [Democracies and democratizations]. Madrid: CIS.

Navas, J. A. (2015, February 10). La CNMC fija en 48.000 millones la factura de la corrupción en la contratación pública [CNMC estimates the cost of corruption practices in public procurement in $\mathbf{4 8 0 0 0}$ millions]. El Confidencial. Retrieved from https://www. elconfidencial.com/empresas/2015-02-10/la-cnmccifra-en-el-4-5-del-pib-el-coste-de-la-corrupcion-enla-contratacion-publica_706560/

Paleo, N., \& Alonso, A. (2014). ¿Es solo una cuestión de austeridad? Crisis y políticas de género en España [Is it just a matter of austerity? Crisis and gender policies in Spain]. Revista de Investigaciones Feministas, 5, 36-68.

Pavolini, E., León, M., Guillén, A. M., \& Ascoli, U. (2015). From austerity to permanent strain? The EU and welfare state reform in Italy and Spain. Comparative European Politics, 13, 56-76.

Plataforma CEDAW Sombra-España. (2015, July 2). Nota de prensa la ONU suspende a España en igualdad de género [Press briefing note: Spain fails on gender equality according to the UN]. Plataforma CEDAW Sombra-España. Retrieved from https:// cedawsombraesp.wordpress.com/2015/07/02/notade-prensa-la-onu-suspende-a-espana-en-igualdad-de -genero

Riveiro, A. (2017, May 23). Unidos Podemos intenta sumar a los nacionalistas a su moción para centrar el foco en el PSOE [Unidos Podemos tries to include the nationalists in their motion to put the focus on the PSOE]. El Diario. Retrieved from https://www. eldiario.es/politica/Unidos-Podemos-intenta-nacio nalistas-PSOE_0_646736280.html\#documento

San José, B. (2015). Igualdad versus austeridad: Resistencia, protestas y propuestas del movimiento feminista [Equality vs austerity. Resistance, protests and proposals from the feminist movement]. Revista de investigaciones feministas, 5, 185-206.

Siim, B., \& Mokre, M. (Eds.). (2013). Negotiating gender and diversity in an emergent European public sphere. Basingstoke: Palgrave.

Stensota, H., Svensson, R., \& Wängnerud, L. (2015). Gender and corruption: The mediating power of institutional logics. Governance: An International Journal of Policy, Administration, and Institutions, 28(4), 475-496.

Sung, H. (2012). Women in government, public corruption, and liberal democracy: A panel analysis. Crime Law Soc Change, 58, 195-219.

Tarrow, S. (2011). Power in movement. Social movements and contentious politics. Cambridge: Cambridge University Press.

Tilly, C. (2007). Democracy. Cambridge: Cambridge University Press.

Torcal, M. (2014). The decline of political trust in Spain and Portugal: Economic performance or political re- 
sponsiveness? American Behavioral Scientist, 58(12), 1542-1567.

Tripp, A. (2013). Political systems and gender. In G. Waylen, K. Celis, J. Kantola, \& L. Weldon (Eds.), The Oxford handbook of gender and politics (pp. 514-534). Oxford: Oxford University Press.

Valiente, C. (2006). Spain at the vanguard in European gender equality policies. In S. Roth (Ed.), Gender politics in the expanding European Union (pp. 101-117). New York, NY: Berghanh.

Verloo, M. (2017). Episteme, polity and inequality regimes: New dynamics and configurations. Paper presented at ECPR Joint Sessions, Nottingham, UK.

Villoria, M., Jiménez, F., \& Revuelta, A. (2014). Corrup- tion perception and collective action: The case of Spain. In J. Mendilow \& I. Peleg (Eds.), Corruption in the contemporary world: Theory, practice and hotspots (pp. 197-222). New Jersey, NJ: Lexington Books.

Vleuten van der, A. (2007). The price of gender equality. Aldershot: Ashgate.

Walby, S. (2009). Globalization and inequalities: Complexity and contested modernities. London: Sage.

Walby, S. (2015). Crisis. Cambridge: Polity.

Waylen, G. (2007). Engendering transitions. Women's mobilization, institutions and gender outcomes. Oxford: Oxford University Press.

\section{About the Authors}

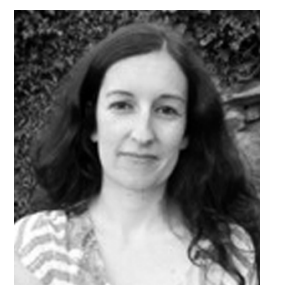

Alba Alonso is Lecturer at the Department of Political Science and Sociology of the University of Santiago de Compostela (Spain). Her main research areas refer to the implementation of gender equality policies, federalism, and the women's movement. Her work has been published in Politics \& Gender, Social Politics, European Journal of Women's Studies, and European Political Science, and in collective books like Institutionalizing Intersectionality? The Changing Nature of European Equality Regimes, edited by Andrea Krizsan, Hege Skjeie and Judith Squires (Palgrave Macmillan, 2012).

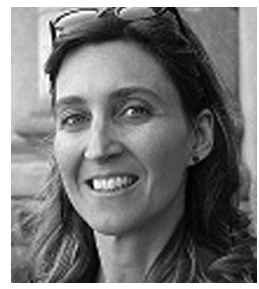

Emanuela Lombardo is Senior lecturer at the Department of Political Science and Administration of Madrid Complutense University (Spain). She works on gender equality policies (European Union, Spain) and feminist approaches to political analysis. Her latest monographs are Gender and Political Analysis (with Johanna Kantola, Palgrave, 2017) and The Symbolic Representation of Gender (with Petra Meier, Ashgate, 2014). She has edited, with Petra Meier and Mieke Verloo, the 2017 Special Issue 38(1) 'Policymaking from a gender+ equality perspective' for the Journal of Women, Politics, and Policy. 